\title{
MODERNIZATION OF SAINT PANCRAS AND KING'S CROSS RAILWAY STATIONS IN LONDON
}

\author{
Anna JÓŹWIK ${ }^{1}$ \\ Warsaw University of Technology, Faculty of Architecture, Warsaw, Poland
}

\begin{abstract}
The article concerns the renovation and modernization of two London railway stations St. Pancras and King`s Cross. Both stations were built in the middle of the nineteenth century and are an example of industrial heritage. A characteristic feature that distinguishes the two buildings is the metal (iron) structure with a glass canopy. The St. Pancras railway station was characterized by a hall with the largest span in the world, and today is one of the leading examples of using iron in the development of architecture and building structures. Both stations have experienced periods of flourishing and stagnation throughout their history. There were even plans to demolish the old stations and build new facilities and in their place. Now, after the successful modernization of St. Pancras and King's Cross railway stations, they serve as good examples of the adaptation of transport utilities to modern needs, while respecting their historic structure. The problems that the designers and contractors were faced with during the renovation and modernization of the two London stations also deserve attention.
\end{abstract}

Keywords: modernization, railway stations, iron structures, London

\section{HISTORY OF SAINT PANCRAS AND KING'S CROSS RAILWAYS STATIONS IN LONDON}

The history of the Saint Pancras and King's Cross railways station in London dates back to the middle of the XIX century and is connected with the development of rail transport in the British Kingdom. Where London is concerned, the decision of the Parliamentary Committee of 1846, according to

\footnotetext{
${ }^{1}$ Corresponding author: Warsaw University of Technology, Faculty of Architecture, Koszykowa st 55, 00-659 Warszawa, e-mail: anna-jozwik@wp.pl
} 
which it was decided not to construct large railway stations in the center of the city proved to be key [4]. In turn, smaller facilities appeared scattered around its outskirts, including Saint Pancras and King's Cross. These train stations are located in the direct vicinity of each other, on Euston Road in the northern part of London, where historically the main roads leading into the city from the north were located. The region is also named King's Cross.

\subsection{Construction of King's Cross Station}

In 1852, King's Cross station was made available for use by the Great Northern Railway line. The actual station had actually been operational since 1850, because of the Great Exhibition which took place in London. The designer of the station was Lewis Cubitt, who in cooperation with engineers John and William Jay presented a project design for a two-bay hall measuring $244 \mathrm{~m} \mathrm{(800}$ feet) in length, with the construction based on arches spanning $32 \mathrm{~m}$ (105 feet) each, and covered with glass. At the time that the building was made available to passengers, the arches were constructed from glued timber and, in later years (1869 and 1887), changed to iron constructions of the same shape. In the train station hall, divided in the middle by a masonry arcade wall, there were eight platforms. A wing with rooms connected with servicing passengers as well as offices was located along the western wall of the station. An elevation in the form of a masonry brick wall with a yellow hue, with two giant arched windows and entrance arcades was designed in the front. The wall was $66 \mathrm{~m}$ in height (216 feet). A $34 \mathrm{~m}$ (112 feet) high clock tower was placed in the middle. King's Cross station was, at the time, the largest railway station in the British Kingdom. In 1854, the Great Northern Hotel was built just alongside it, also designed by Lewis Cubitt. Over the course of time, the layout of the platforms was modified a few times, and temporary pavilions would appear in the square in front of the station. The last construction of this type took place in the years 1972-1973 and has survived until the time of modernization in 2012.

\subsection{Realization of Saint Pancras Railway Station}

The histories of King's Cross and Saint Pancras railway stations are inextricably linked to one another. The development of the railway lines and expansion of operators responsible for the maintenance and construction of the infrastructure played a part in the construction of another train station in London - Saint Pancras, built for the Midland Railway in 1868. Up until the time this station was built, the Midland Railway used the Great Northern Railway line and King's Cross station, paying for its lending. Following unsuccessful negotiations in the year 1862, a decision was made to build its own railway station [5]. The main engineer working for the Midland Railway - William 

IN LONDON

Henry Barlow, became responsible for this task, cooperating with Rowland Mason Ordish, a construction engineer possessing much experience in what were, at the time, very modern constructions, such as the suspended Victoria Bridge in London or Crystal Palace built specifically for the Great Exhibition. Based on the analyses of projects, it was decided to create a single-bay train station hall with a load-bearing construction in the form of twenty-five arches made of iron and partially covered by glass. A characteristic feature giving the hall its shape was an arch in the cross-section, measuring $1.8 \mathrm{~m}$ (6 feet) in height, with a pointed tip on the roof ridge (Gothic arch). The spacing between the arches was approximately $9 \mathrm{~m}$ (29 feet). The constructed train station hall spanned $75 \mathrm{~m}$ (245 feet), with a height of $30.5 \mathrm{~m}$ (100 feet) and was, at the time, the largest construction of its kind in the world.

Due to the necessity of running a railway line over the Royal Canal, it was decided that the floor of the train station will be raised in relation to the level of Euston Road. This required the use of a system of cast-iron posts and iron beams spaced on a construction net measuring $4.6 \times 4.6 \mathrm{~m}$. It was planned that barrels of beer for one of the breweries will be stored on this floor.

From the front of the Saint Pancras station, opened to passengers in 1868, The Midland Grand Hotel was built in 1873. Following a contest organized by the Midland Railway, Sir George Gilbert Scott was selected as the designer of this building. In his project, a clock tower became the main dominant, which is believed to have been inspired by Big Ben in Westminster. The entire building, including a hotel and train station section, was maintained in a neo-Gothic style, referring back to the Italian Gothic style.

Changes in the ownership structure of railway operators influenced the later condition of the railway station. The most difficult time occurred in the 60's of the XX century, when the demolitions of St. Pancras station along with the building of what used to be the hotel, and King's Cross Station were considered. Leading the social campaign to protect these architectural structures was the poet sir John Betjeman. As a result, not only was the decision reversed, but great success was achieved in listing the buildings on the National Heritage List under the highest category, as Grade I Historic Buildings, alongside such buildings as, for example, Westminster. Unfortunately, since that time, practically no investments were carried out, causing the technical condition of St. Pancras Station to severely deteriorate.

\section{MODERNIZATION OF SAINT PANCRAS STATION}

The final decision regarding the modernization of Saint Pancras railways station and architectural and urban planning transformations in its surroundings was 
made following the opening of the Channel Tunnel (Eurotunel) under the English Channel in 1994. The station was chosen as the destination for railway lines connecting London with Paris, as well as other cities on the European Continent. A consortium of companies was called upon to create the project design for and manage works connected with the modernization of the station, i.e.: Bechtel, Systra, Halcrow and Arup. Alastair Lansley, working on behalf of Rail Link Engineering, was appointed as the chief architect [5]. All works connected with the modernization of the historic railway station were consulted with English Heritage, the London Borough of Camden, and the Victoria Society [1]. Saint Pancras International Station was once again opened to passengers in October of 2007.

\subsection{Expansion of the station}

The necessity of expanding the station due to the need for a greater number of platforms and extending their length appeared in the framework of changes planned for Saint Pancras. Along with these plans, the problem of how to connect the old part of the station with the newly created section arose. Reference to the neo-Gothic style was not a promising solution, therefore it was decided that the added-on building is to differ significantly from the historical one. The new section of the station was created on the north, as an extension of what was, at the time, the hall. A building on a steel frame construction was erected, with large amounts of glass, aluminum blinds and an overhanging roof. A glass hall with the main entrance to the station was designed between the old and new part of the station, from the direction of Pancras Road (Fig. 1).

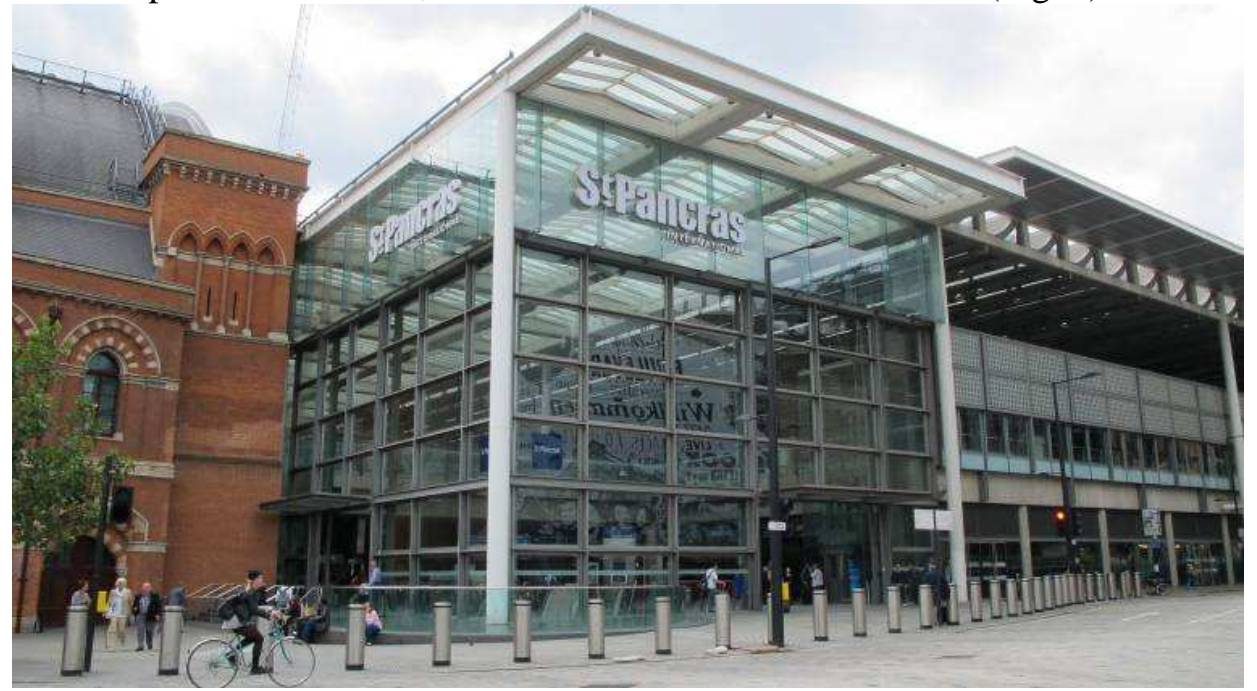

Fig. 1. Main entrance to Saint Pancras Station 


\subsection{Renovation of roof in the historic hall of the train station}

Following the structural analysis of the technical condition of the railway station, the roof turned out to be better than anticipated. The majority of loadbearing elements in the form of arches, lattice beams of the second row and cross ties did not need to be replaced, requiring only possible local repairs. The glass covering of the roof, on the other hand, was changed. The panes in the roof designed by Barlow were installed in wooden frames. This time around, laminated glass attached to aluminum profiles, creating a folded plate roof system of glass panes along the length of the hall, was applied. Such a framework was returned to the XIX century concept in order to facilitate the runoff of rainwater.

During the renovation of the train station hall, much attention was given to the color of paint used to coat the construction elements, including those found on the roof. The hall was repainted several times since it had been built. The last color found prior to renovation was dark brown. Analysis confirmed that the construction elements had originally been painted blue, which along with the right overcast, resulted in a disappearing effect of the roof [7]. During renovation, this initial color was brought back (Fig. 2).

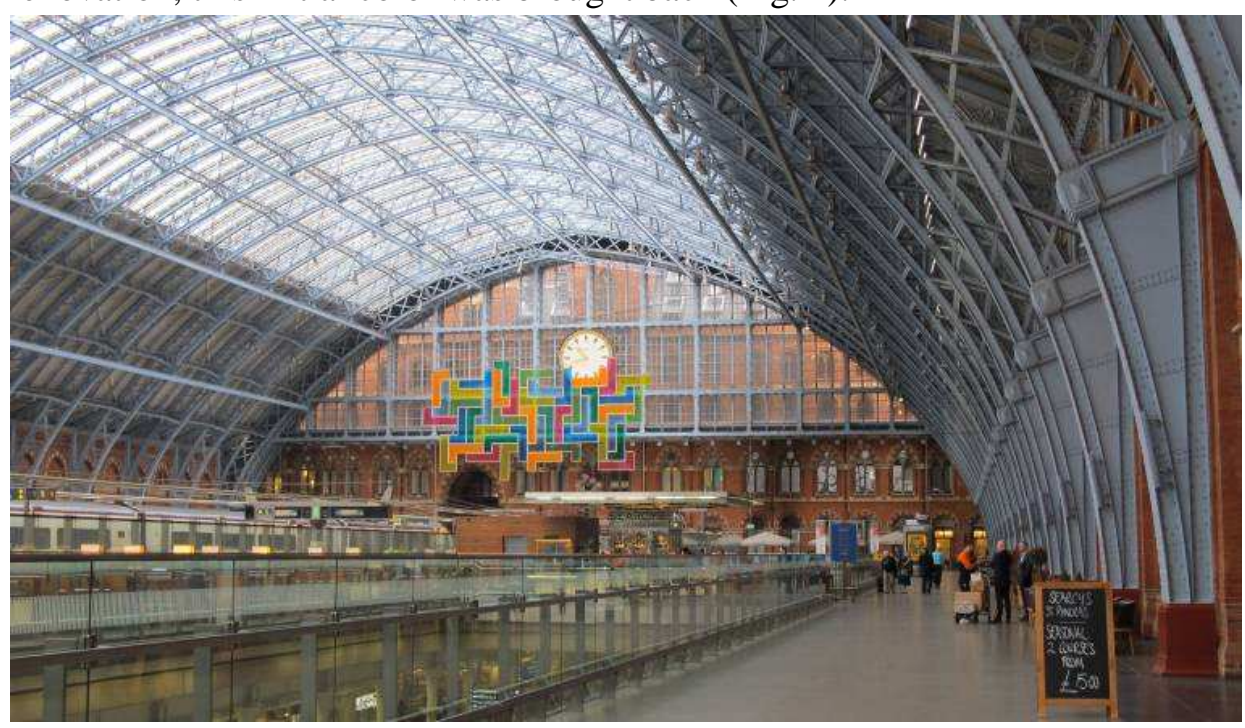

Fig. 2. Saint Pancras Station hall after renovation

\subsection{Arcades}

The new usable space gained on underneath the level of the train station, where barrels of beer were stored, was named the arcades. In the project design, this 
part of the train station was to constitute an important element of its modernization. A waiting room along with an extensive program of use covering, among others: information, sale and gastronomic points [3] was planned in the arcades. Carrying out such assumptions required changes in the historic fabric. In order for the space to be lit by daylight and easily connected with the level of the train station, it was partially necessary to open the floor between the hall and the arcades. The actual floor needed repair work and modifications in its construction. From the carried out statistical calculations it turned out that at its current load, stress levels in structural elements will be exceeded. That is why a solution was assumed in which a reinforced concrete slab measuring $40 \mathrm{~cm}$ in thickness and directly supported by the original columns was added. The cast-iron posts revealed good load-bearing capacity, as well as the brick and stone foundations reinforced with concrete, the state of which enabled them to bear higher loads.

\subsection{Renovation of masonry walls}

Renovation works on masonry walls with stone elements were divided into fields: interior elevations around the platforms in the train station hall, masonry constructions on the floor below the train station hall, eastern elevation from Pancras Road, western elevation from Midland Road [5].

The facades were cleaned due to atmospheric pollution and repaired. Bricks which the masonry walls are made of are no longer produced, and those which are available differ in terms of color and texture. However, a producer was found who was able to hand-make bricks from almost the same clay, thanks to which a product similar to the original XIX century brick was obtained.

The western elevation turned out to be in the worst technical condition. Due to significant damage, a decision was made to take it apart and replace it with a replica.

\section{MODERNIZATION OF KING'S CROSS}

In the middle of 2005, modernization plans for King's Cross prepared by John McAslan + Partners were presented [8]. In the assumptions, transformations covered elements of the renovation and adaptation of the historical train station building, but also architectural solutions which provided the possibility to obtain a fully modern train terminal, which, connected with a metro station, will become an importation transportation hub. The train station was made available to passengers in March 2012. 


\subsection{Renovation and adaptation of the train station}

In the scope of renovation works, the southern elevation was cleaned and repaired from Euston Road. The pavilions from the 70's were also taken apart, thanks to which the front of the main hall designed by Cubitt became well visible from the newly created King's Cross Square. The platforms and roofs over them were remodeled on the inside. The glass elements were completely replaced and photovoltaic panels additionally installed (Fig. 3).

The East Wing - Eastern Range was subjected to renovation, with the most visible change pertaining to the reception, with an arched window at the edge of the front elevation.

In the West Wing - Western Range, in addition to restoring the historic fabric (e.g. ticket hall), and rebuilding a part of the wing destroyed during World War II, a lot of work was put into improving the functionality of rooms designated for train station workers and train operators [6].

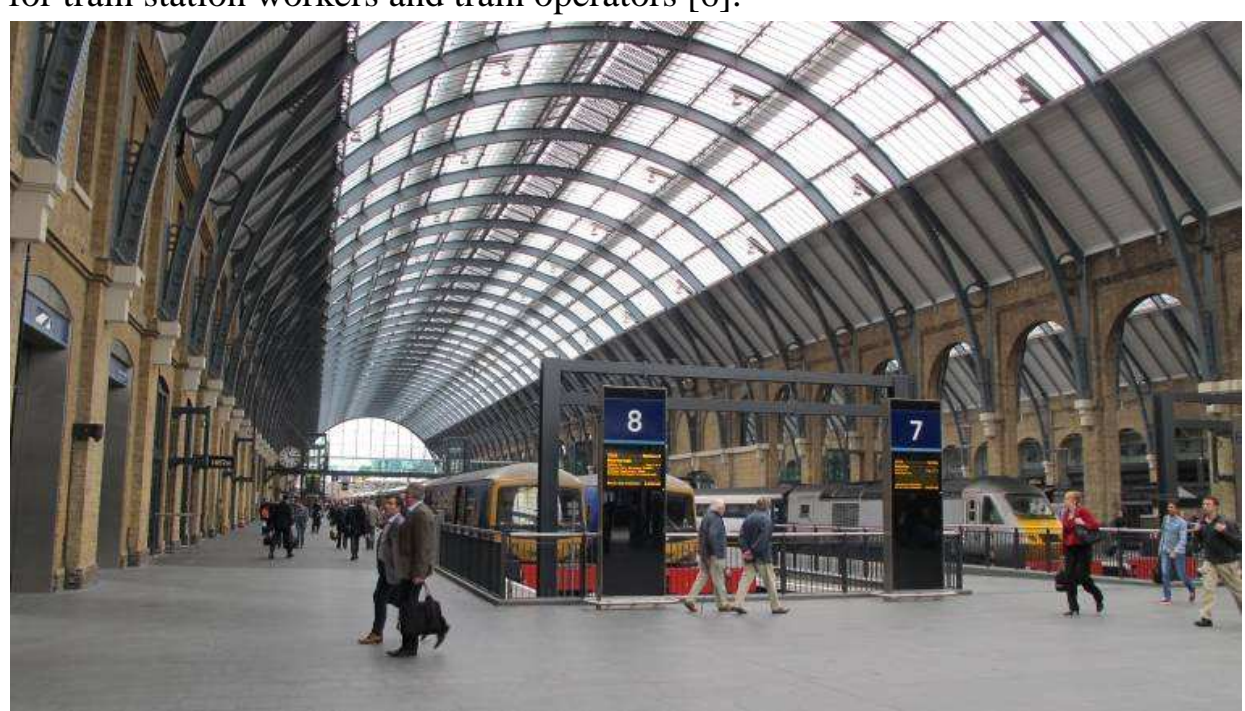

Fig. 3. King's Cross Station Hall after renovation

\subsection{Expansion of the train station}

The most eye-catching element of architectural transformations in the scope of modernization works on King's Cross Station is the Western Concourse Hall added on next to the Western Range Wing. The Hall is in the shape of a semicircle and covered with a construction in the form of a metal mesh cover supported peripherally by posts in the shape of trees and supports in the shape of a funnel which is a part of the mesh cover. The main entrance to the train station hall leads through this building, running through the ticket hall at the 
ground floor level or the entresol, from which a glass footbridge leads to the platforms. Access from the footbridge is ensured by lifts and escalators.

\section{CONCLUSIONS}

Both cases of modernization are good examples of adapting train stations to their current utility requirements while, at the same time, respecting their historic structure.

\section{REFERENCES}

1. Allington-Jones L.: The Phoenix: The Role of Conservation Ethics in the Development of St Pancras Railway Station (London, Uk), Journal of Conservation \& Museum Studies, 11, 1 (2013) 1-21.

2. Bennett R., Gardner I., Gates-Sumner M., Lansley A.: St Pancras Station and kings Cross Railway Lands, The Arup Journal, 1 (2004) 46-54.

3. Gothic beauty - the renovation of St. Pancras Station in London. Detail 9 (2009) 514.

4. King Cross Conservation Area Statement. Borough of Camden.

5. Lansley A., Durant A., Dyke A., Gambrill B., Shelton R.: The Transformation of St Pancras Station, Londyn, Laurence King 2008.

6. McAslan J.: All Change! Cubbitt's Victorian marvel transformed by $21^{\text {st }}$ century design. The Arup Journal, 2 (2012) 8-11.

7. St Pancras Station roof is sky blue heaven, http://www.bdonline.co.uk/stpancras-station-roof-is-sky-blue-heaven/3094640.article [dostęp: 27.12. 2014].

8. Woodman E.: King's Cross western concourse by John McAslan and Partners, http://www.bdonline.co.uk/kings-cross-western-concourse-byjohn-mcaslan-and-partners/5033806.article [dostęp: 27.12.2014].

\section{MODERNIZACJA DWORCÓW KOLEJOWYCH SAINT PANCRAS I KING`S CROSS W LONDYNIE}

\section{Streszczenie}

Artykuł dotyczy renowacji i modernizacji dwóch londyńskich dworców kolejowych położonych w bezpośrednim swoim sąsiedztwie - dworca Saint Pancras oraz King`s Cross. Oba dworce zostały wybudowane w połowie wieku XIX i stanowią przykład dziedzictwa kultury przemysłowej. Cechą charakterystyczną, wyróżniającą oba obiekty, 
było zastosowanie w halach dworcowych konstrukcji metalowych, wówczas żeliwnych przekrytych szkłem. W przypadku dworca Saint Pancras była to hala o największej rozpiętości na świecie i do dziś stanowi jeden z czołowych przykładów zastosowania żelaza w rozwoju architektury i konstrukcji budowlanych.

Oba dworce w swojej historii przechodziły okresy rozkwitu i stagnacji. Pojawiały się również pomysły, aby wyburzyć stare dworce, a na ich miejscu wybudować nowe obiekty. Obecnie po udanej modernizacji dworce Saint Pancras i King`s Cross stanowia dobry przykład dostosowania funkcji transportowych do współczesnych potrzeb użytkowych z uwzględnieniem poszanowania struktury zabytkowej. Warto również zwrócić uwagę na problemy samej renowacji z jakimi zmierzyli się projektanci i wykonawcy modernizacji dwóch londyńskich dworców.

Słowa kluczowe: modernizacja, dworce kolejowe, konstrukcje z żelaza, Londyn

Editor received the manuscript: 23.11 .2014 
